\title{
SERUM BILIRUBIN CORRELATES WITH SERUM ADIPOKINES IN NORMAL WEIGHT AND OVERWEIGHT ASYMPTOMATIC ADULTS
}

\author{
Ana Petelin ${ }^{1}$, Mihaela Jurdana ${ }^{1}$, Zala Jenko Pražnikar ${ }^{1}$ and Lovro Žiberna ${ }^{2}$ \\ ${ }^{1}$ Faculty of Health Sciences, University of Primorska, Izola, Slovenia; \\ ${ }^{2}$ Institute of Pharmacology and Experimental Toxicology, Faculty of Medicine, \\ University of Ljubljana, Ljubljana, Slovenia
}

\begin{abstract}
SUMMARY - Overweight and obesity are considered as chronic low-grade inflammation accompanied by imbalanced production of adipokines. The aim of this study was to elucidate the relationship between serum bilirubin, which is an endogenous antioxidant with anti-inflammatory activity, and pro- and anti-inflammatory serum adipokines in asymptomatic normal weight and overweight individuals. Healthy men and women aged 25-49 participated in this cross-sectional study. All participants underwent fasting serological measurements of adipokines, interleukin-6, tumor necrosis factor alpha (TNF- $\alpha$ ), C-reactive protein (CRP), total and direct serum bilirubin, and other biochemical parameters. Participants were divided into normal weight and overweight groups. We found a significant negative association between total bilirubin and CRP,TNF- $\alpha$, visfatin and resistin values, and a significant positive association between total bilirubin and adiponectin values in both normal-weight and overweight groups. Importantly, after adjusting for body mass index, we also found a significant negative association between total serum bilirubin levels and both visfatin and CRP serum levels. Moreover, visfatin, resistin and CRP were predictors of the total serum bilirubin levels.
\end{abstract}

Key words: Adipokines; Bilirubin; C-reactive protein; Overweight; Obesity; Cross-sectional studies

\section{Introduction}

Imbalance in the production of adipocytokines (adipokines) from adipose tissue is involved in various pathological states, such as metabolic syndrome, hyperlipidemia, hypertension, atherosclerosis and diabetes mellitus, among others ${ }^{1-3}$. Adipokines determine adipose tissue function, fat distribution, fat mass, liver function, insulin sensitivity; and importantly, visceral fat accumulation also has an impact on adipokine secretion profile ${ }^{4}$ In addition, adipose tissue via adipokines plays an important role in the regulation of im-

Correspondence to: Lovro Žiberna, PhD, Institute of Pharmacology and Experimental Toxicology, Faculty of Medicine, University of Ljubljana, Korytkova 2, 1000 Ljubljana, Slovenia

E-mail: lovro.ziberna@mf.uni-lj.si

Received May 14, 2018, accepted September 11, 2019 mune response and systemic inflammation. In this view, action of adipokines is either pro-inflammatory (e.g., leptin, resistin, interleukin-6 (IL-6), tumor necrosis factor alpha (TNF- $\alpha)$ ), or anti-inflammatory (e.g., adiponectin) ${ }^{5}$.

It remains a challenge to identify asymptomatic individuals who are at an increased risk of developing metabolic syndrome. Serum bilirubin is a strong endogenous antioxidant with anti-inflammatory properties $^{6,7}$. Several epidemiological and large-scale population studies have shown that higher serum bilirubin levels protect against the development of diabetes mellitus, hypertension, coronary artery disease, stroke, and cardiovascular diseases $(\mathrm{CVD})^{7-12}$. Serum bilirubin levels were also inversely correlated with the prevalence of metabolic syndrome, which is considered as a pre-diabetes state ${ }^{9,10}$. Moreover, bilirubin has been 
recently speculated as a potential pre-disease biomarker for the development of metabolic syndrome in asymptomatic middle-aged individuals ${ }^{13}$. In this perspective, bilirubin can be considered as surrogate endpoint for cardiovascular or metabolic diseases, especially if measured longitudinally over time in single patient to reflect positive or negative changes due to lifestyle modification or therapeutic approaches. This consistent pathophysiological evidence combined with the epidemiological data opens up the perspective for bilirubin to be used as a biomarker for therapeutic interventions.

Overweight and obese individuals have increased serum levels of pro-inflammatory adipokines such as leptin, TNF- $\alpha$, IL- 6 , resistin, and visfatin ${ }^{14}$. Interestingly, resistin that is released within fat tissue acts on adipocytes directly, thus leading to insulin resistance independently of body mass index (BMI ${ }^{15}$. In contrast to other adipokines, serum levels of adiponectin decrease in obese subjects ${ }^{16}$. Furthermore, hypoadiponectinemia is associated with visceral fat accumulation, and is also closely linked to higher waist circumference, blood pressure, fasting insulin, insulin resistance index, total cholesterol, low density lipoprotein (LDL) cholesterol, very low density lipoprotein (VLDL) cholesterol, and triacylglycerols ${ }^{17,18}$. Accordingly, decreased serum levels of adiponectin are considered as a new hypothesis to explain the pathophysiology of metabolic syndrome ${ }^{19}$.

Here we proposed the idea that serum adipokines and serum bilirubin might have direct correlation already in the asymptomatic individuals, i.e. in the early pre-disease states. The proof of this concept could open the perspective of using longitudinal screening of serum bilirubin values as a biomarker for cardiovascular and metabolic pre-disease states, in which reversible changes with lifestyle modification are still possible. Up to date, the role of adipokines in respect to bilirubin is described in the literature mainly in studies dealing with hepatic diseases. On the other hand, induction of bilirubin synthetic enzyme heme oxygenase- 1 (HO-1) in adipocytes improved adipocyte function and adipose remodeling by increasing adiponectin levels ${ }^{20}$.

In a recent clinical study, serum bilirubin was positively correlated to adiponectin ${ }^{21}$. Therefore, the aim of our study was to elucidate the relationship between serum adipokines and serum bilirubin levels in asymptomatic normal weight and overweight individuals.

\section{Materials and Methods}

\section{Study population}

In this cross-sectional study, 96 apparently healthy participants of Caucasian origin were included. Participants were recruited by internet and media advertisement and selected by the following exclusion criteria: (i) having $19 \geq \mathrm{BMI} \geq 35$; (ii) having drug therapy for lipid disorders, or taking non-steroidal anti-inflammatory drugs (NSAIDs); (iii) having any cardiovascular, endocrine, acute or chronic inflammatory disease, including diabetes mellitus type 2; (iv) being a smoker; and (v) not completing the questionnaires, or not reporting stable weight over the last three months (loss or gain $<3 \%$ of the subject's weight was tolerated). All volunteers were fully informed on the study procedures, and written informed consent was obtained from each subject upon enrolment. The study was conducted with approval from the Slovenian National Medical Ethics Committee (No. 56/08/11 bis), and the experimental protocol was in accordance with the Declaration of Helsinki from 2004.

\section{Measurement of body composition}

Subject anthropometric measures, including height, weight, waist and hip circumference were performed by the protocol previously described ${ }^{13}$. All participants were subjected to the following measurements: (i) body weight was recorded to the nearest $0.1 \mathrm{~kg}$, and height to the nearest $0.1 \mathrm{~cm}$ in standing position using a Leicester Height Measure (Invicta Plastics Limited, Oadby, England); (ii) waist circumference was measured midway between the costal edge and iliac crest; (iii) calculating BMI; and (iv) body composition analyses (total percentage of body fat (\% BF) and trunk fat (\% TF)) were performed using a body composition analyzer (BIA) Tanita BC 418MA (Tanita Corporation, Arlington Heights, IL, USA). Overweight group consisted of all participants that had at least two of three following characteristics: (i) BMI $\geq 25 \mathrm{~kg} / \mathrm{m}^{2}$; (ii) visceral obesity - waist circumference $(\geq 94 \mathrm{~cm}$ (men) and $\geq 80 \mathrm{~cm}$ (women); and (iii) $\%$ of total fat $(\geq 21.5 \%$ (men) and $\geq 32 \%$ (women).

\section{Serum measurements}

After overnight fast, whole blood samples for different biochemical analyses were collected in the 
morning into red topped tubes (Becton-Dickinson, Rutherford, USA). After whole blood collection, the blood was left at room temperature for 20 minutes. Then, the clot was removed immediately by centrifugation; the resulting supernatant was transferred into a clean polypropylene tube frozen and stored at $-20{ }^{\circ} \mathrm{C}$ until analysis.

Cytokines, including IL- 6 and TNF- $\alpha$, but also adipokine visfatin were measured in serum, as previously described ${ }^{22}$. Briefly, serum levels of visfatin, IL-6, TNF- $\alpha$ and adiponectin were determined in duplicate on a microplate reader (Tecan, Männedorf, Switzerland) using human ELISA kit for visfatin (BioVision, Mountain View, CA, USA), IL-6 and TNF- $\alpha$ (Thermo Fischer Scientific Inc., Rockford, USA), and adiponectin and resistin (BioVendor, Laboratory Medicine Inc., Brno, Czech Republic). Assay sensitivity was $26 \mathrm{ng} / \mathrm{mL}$ for adiponectin and $33 \mathrm{pg} / \mathrm{mL}$ for resistin, whereas inter-assay and intra-assay coefficient of variation $(\mathrm{CV})$ was $<10 \%$ both. In addition, serum concentrations of different biochemical parameters were analyzed using standard techniques, as previously reported $^{13}$. To sum up, using Olympus reagents, serum concentrations of total and direct bilirubin, standard serum blood lipids, including total cholesterol, LDL cholesterol, HDL cholesterol and triacylglycerols but also serum glucose and CRP were measured on an AU 680 analyzer (Beckman Coulter, Pasadena, CA, USA). In addition, serum insulin levels were analyzed on an Abbott Architect 2000 iSR analyzer (Abbott Diagnostics, Abbot Park, IL, USA).

\section{Statistics}

Descriptive statistics was used to analyze data distribution and to summarize the data. Non normally distributed data (concentrations of bilirubin, adiponectin, visfatin, TNF- $\alpha$, LDL cholesterol, triacylglycerols, CRP, and insulin) were logarithmically transformed to approximate normal distribution. In general, data were expressed as mean $\pm \mathrm{SD}$ unless otherwise stated. To analyze the effect of obesity measures on serum bilirubin, adipokines and inflammatory markers, subjects were divided according to obesity measures (body fat, BMI, and waist circumference). Independent Student's t-test was used to compare the two groups. Spearman's correlation analyses were used to detect relationships between fasting serum concentrations of bilirubin and adipokines or inflammatory markers before and after BMI adjustment. Step by step regression analysis was used to explore the predictors of fasting serum concentrations of total bilirubin (dependent variable). Independent variables were adipokines and cytokines. Moreover, hierarchical multiple regression analysis was performed to examine the effects of studied adipokines on serum bilirubin levels. First, general parameters (age and gender) were entered as control variables (step 1), followed by indicators of obesity (waist to hip ratio and body fat mass) (step 2). Then, some other possible confounders such as fasting glucose, insulin, triacylglycerols and total cholesterol were entered (step 3), followed by adipokines and inflammatory markers (step 4). For all statistical analyses, the IBM SPSS version 19.0 (SPSS Inc., Chicago, IL, USA) was used. The level of statistically significant difference between the tested parameters was set at $\mathrm{p}<0.05$.

\section{Results}

\section{Baseline anthropometric and biochemical characteristics}

Some of the previously described anthropometric and biochemical data on the two study groups, i.e. normal weight (16 male and 32 female participants) and overweight (16 male and 32 female participants) are shown in Tables 1 and 2. Participants in the two groups differed in all obesity measures, including BMI, waist to hip ratio, $\% \mathrm{BF}$, and $\% \mathrm{TF}$. The metabolic profile of cytokines and adipokines of the two study groups is shown in Table 2. Subjects in the overweight group had significantly higher levels of fasting insulin, blood lipids, including triacylglycerols, total cholesterol and LDL cholesterol, and lower levels of HDL cholesterol and total bilirubin as compared with the normal weight group. In the overweight group, circulating levels of CRP, IL-6, visfatin, and TNF- $\alpha$ were higher, while adiponectin levels were lower.

\section{Correlation between serum adipokines and bilirubin levels}

Bilirubin is present in serum in conjugated (direct bilirubin) and unconjugated (indirect bilirubin) forms. The sum of both forms results in total bilirubin. Serum bilirubin levels, i.e. total and direct bilirubin, were higher in the normal weight participants in compari- 
Table 1. Anthropometric and biochemical parameters of normal weight and overweight groups, previously published by Jenko-Pražnikar et al. ${ }^{13}$

\begin{tabular}{|l|l|l|l|}
\hline & Normal weight subjects & Overweight subjects & p value \\
\hline Number of participants & 48 & 48 & $\mathrm{NS}$ \\
Gender $(\mathrm{M} / \mathrm{F})$ & $16 / 32(33 \% / 67 \%)$ & $16 / 32(33 \% / 67 \%)$ & $\mathrm{NS}$ \\
Age $($ years) & $37 \pm 6$ & $39 \pm 6$ & $\mathrm{NS}$ \\
BMI $\left(\mathrm{kg} / \mathrm{m}^{2}\right)$ & $21.9 \pm 2.4$ & $29.4 \pm 2.7$ & $<0.001$ \\
Waist to hip ratio & $0.82 \pm 0.07$ & $0.88 \pm 0.09$ & $<0.001$ \\
Body fat $(\%)$ & $21 \pm 6$ & $34 \pm 8$ & $<0.001$ \\
Trunk fat $(\%)$ & $19 \pm 6$ & $33 \pm 6$ & $<0.001$ \\
Fasting glucose $(\mathrm{mmol} / \mathrm{L})$ & $5.0 \pm 0.4$ & $5.2 \pm 0.4$ & $\mathrm{NS}$ \\
Fasting insulin $(\mathrm{unit})$ & $5.4 \pm 1.7$ & $9.2 \pm 4.3$ & $<0.001$ \\
Triacylglycerols $(\mathrm{mmol} / \mathrm{L})$ & $0.94 \pm 0.50$ & $1.38 \pm 0.74$ & $<0.001$ \\
Total cholesterol $(\mathrm{mmol} / \mathrm{L})$ & $5.0 \pm 0.9$ & $5.6 \pm 1.1$ & 0.011 \\
HDL cholesterol $(\mathrm{mmol} / \mathrm{L})$ & $1.5 \pm 0.3$ & $1.3 \pm 0.3$ & 0.001 \\
LDL cholesterol $(\mathrm{mmol} / \mathrm{L})$ & $3.1 \pm 0.7$ & $3.6 \pm 1.0$ & 0.004 \\
CRP $(\mathrm{mg} / \mathrm{L})$ & $0.84 \pm 0.86$ & $3.02 \pm 3.06$ & $<0.001$ \\
Bilirubin-total $(\mu \mathrm{mol} / \mathrm{L})$ & $15.4 \pm 3.1$ & $13.2 \pm 2.8$ & 0.042 \\
Bilirubin-direct $(\mu \mathrm{mol} / \mathrm{L})$ & $2.5 \pm 0.6$ & $2.1 \pm 0.6$ & 0.038 \\
\hline
\end{tabular}

All values are mean $\pm \mathrm{SD} ; \mathrm{M}=$ male; $\mathrm{F}=$ female; $\mathrm{BMI}=$ body mass index; $\mathrm{HDL}=$ high-density lipoprotein; $\mathrm{LDL}=$ low-density lipoprotein; $\mathrm{CRP}=\mathrm{C}$-reactive protein; $\mathrm{NS}=$ nonsignificant .

Comparisons of biochemical and other characteristics between the two groups were completed with the use of one-factor analysis of variance with Bonferroni correction. The mean difference was significant at the 0.05 level.

Table 2. Adipokine levels in normal weight and overweight subjects

\begin{tabular}{|l|l|l|l|}
\hline & $\begin{array}{l}\text { Normal } \\
\text { weight subjects }\end{array}$ & $\begin{array}{l}\text { Overweight } \\
\text { subjects }\end{array}$ & p value \\
\hline $\begin{array}{l}\text { Number of } \\
\text { participants } \\
\text { TNF- } \alpha \\
\text { (pg/mL) }\end{array}$ & 48 & 48 & NS \\
$\begin{array}{l}\text { IL-6 } \\
(\mathrm{pg} / \mathrm{mL})\end{array}$ & $2.0 \pm 1.6$ & $5.2 \pm 3.3$ & $<0.001$ \\
$\begin{array}{l}\text { Adiponectin } \\
(\mu \mathrm{m} / \mathrm{mL})\end{array}$ & $7.0 \pm 3.8$ & $3.2 \pm 0.9$ & 0.021 \\
$\begin{array}{l}\text { Resistin } \\
(\mu \mathrm{m} / \mathrm{mL})\end{array}$ & $8.0 \pm 2.5$ & $8.6 \pm 2.7$ & 0.009 \\
$\begin{array}{l}\text { Visfatin } \\
(\mathrm{ng} / \mathrm{mL})\end{array}$ & $2.0 \pm 0.6$ & $4.2 \pm 0.9$ & 0.002 \\
\hline
\end{tabular}

All values are mean \pm SD; IL-6 $=$ interleukin 6 ; TNF- $\alpha=$ tumor necrosis factor alpha; NS = nonsignificant.

Comparisons of biochemical and other characteristics between the two groups were completed with the use of one-factor analysis of variance with Bonferroni correction. The mean difference was significant at the 0.05 level. son to the overweight participants. Both forms of bilirubin correlated in the same manner with the increasing number of metabolic syndrome parameters, as published previously ${ }^{13}$. Associations of total serum bilirubin with both serum adipokines and pro-inflammatory cytokines are shown in Table 3 and Figure 1.

Table 3. Spearman correlation coefficients of fasting serum levels of total bilirubin with adipokines and after adjustment for BMI

\begin{tabular}{|l|l|l|l|l|}
\hline $\begin{array}{l}\text { Independent } \\
\text { variable }\end{array}$ & \multicolumn{2}{|l|}{ Total bilirubin } & \multicolumn{2}{l|}{$\begin{array}{l}\text { Total bilirubin after } \\
\text { adjustment for BMI }\end{array}$} \\
\hline & $\mathrm{r}$ & $\mathrm{p}$ & $\mathrm{r}$ & $\mathrm{p}$ \\
\hline CRP & -0.33 & 0.001 & -0.33 & 0.001 \\
TNF- $\alpha$ & -0.29 & 0.018 & -0.17 & 0.251 \\
Visfatin & -0.31 & 0.021 & -0.29 & 0.034 \\
Adiponectin & 0.24 & 0.024 & 0.14 & 0.321 \\
Resistin & -0.25 & 0.019 & -0.24 & 0.059 \\
IL-6 & 0.14 & 0.151 & 0.10 & 0.434 \\
\hline
\end{tabular}

$\mathrm{BMI}=$ body mass index; $\mathrm{CRP}=\mathrm{C}$-reactive protein; $\mathrm{IL}-6=$ interleukin 6 ; TNF- $\alpha=$ tumor necrosis factor alpha 
A

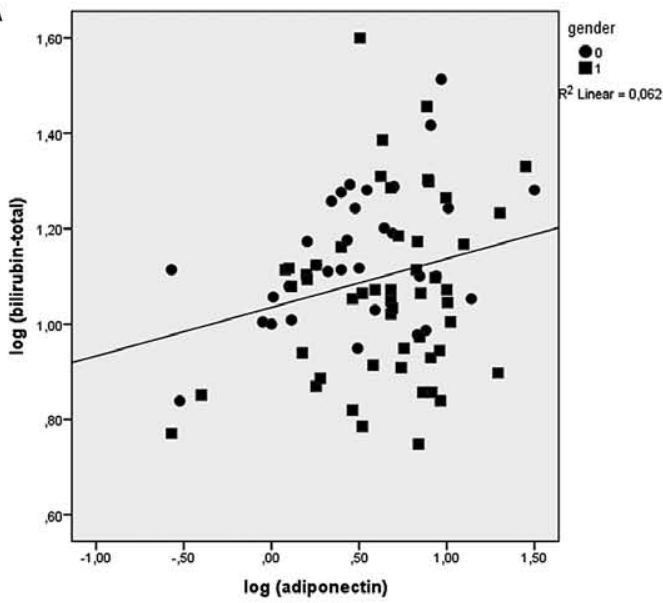

C

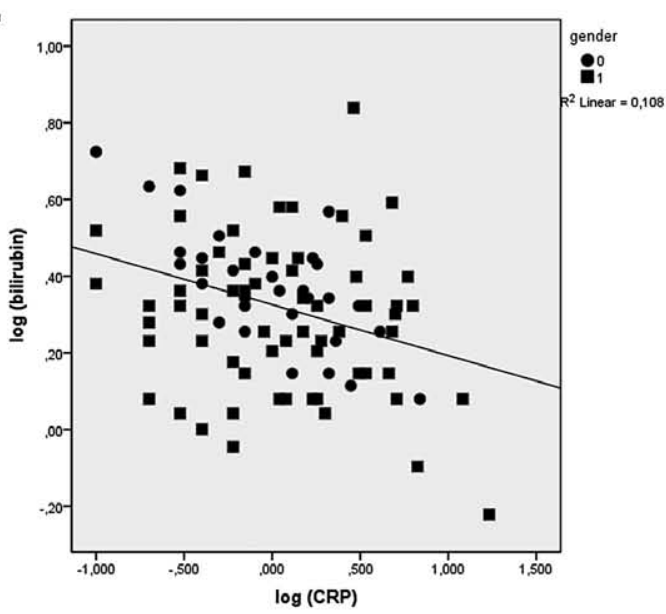

$\mathrm{E}$

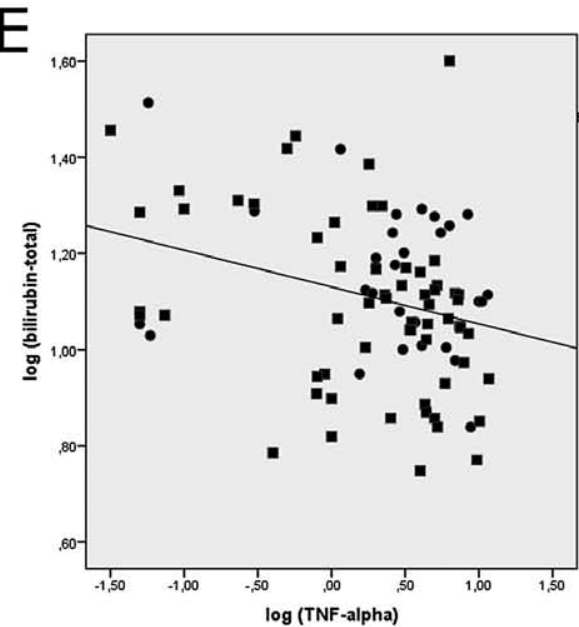

B

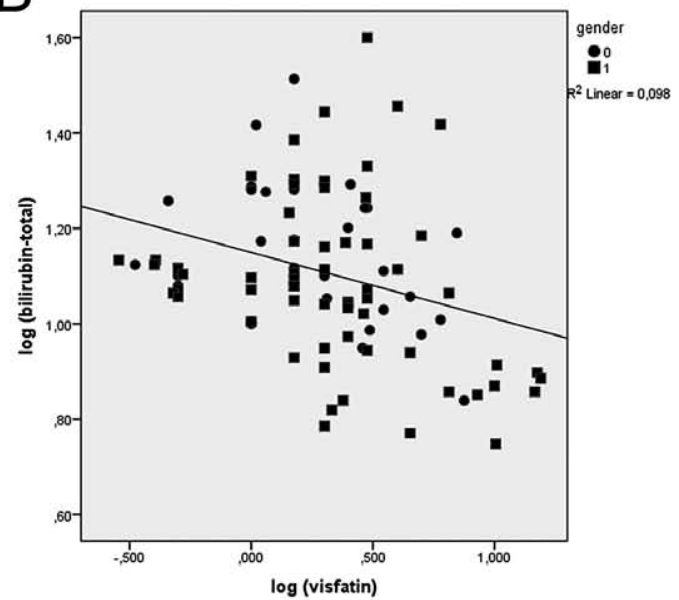

$\mathrm{D}$

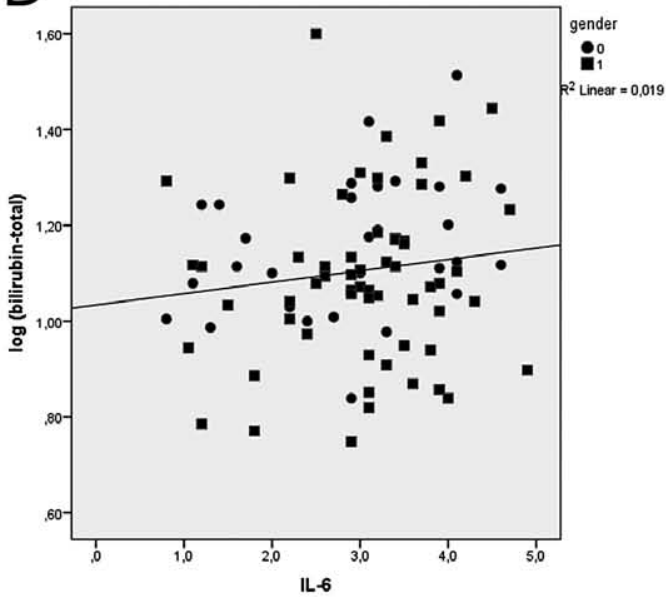

$\mathrm{F}$

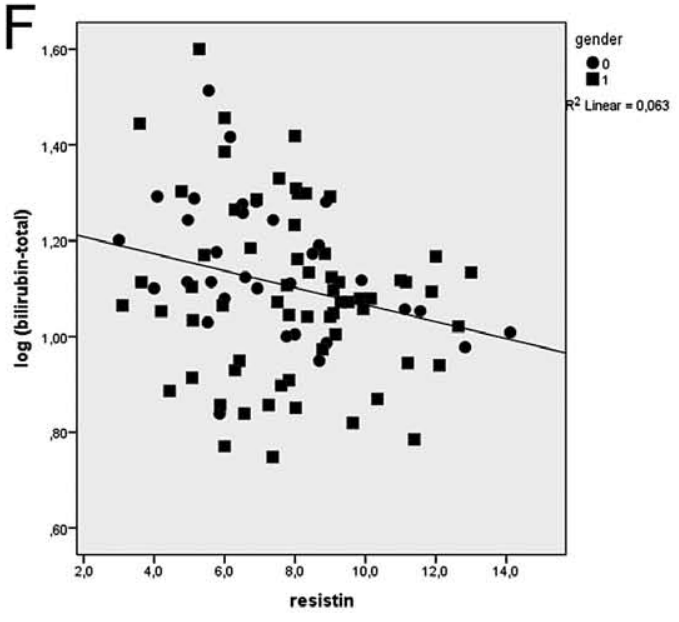

Fig. 1. Correlations between total serum bilirubin levels and serum cytokines and adipokines levels.

(A) Serum adiponectin; (B) serum visfatin; (C) C-reactive protein (CRP); (D) serum interleukin-6 (IL-6); (E) serum tumor necrosis factor alpha (TNF-alpha); (F) serum resistin. Results are presented for male (0) and female (1) participants (circles and squares). Pearson's correlation analysis was performed ( $\mathrm{N}=96)$. 
Table 4. Results of linear regression analysis (by gender) between serum bilirubin (total and direct) level and other variables

\begin{tabular}{|l|l|l|l|l|}
\hline Independent variable & \multicolumn{2}{|c|}{ Total bilirubin } & \multicolumn{2}{c|}{ Direct bilirubin } \\
\hline & $\mathrm{r}(\mathrm{M} / \mathrm{F})$ & $\mathrm{p}(\mathrm{M} / \mathrm{F})$ & $\mathrm{r}(\mathrm{M} / \mathrm{F})$ & $\mathrm{p}(\mathrm{M} / \mathrm{F})$ \\
\hline $\mathrm{CRP}$ & $-0.71 /-0.28$ & $<0.0001 / 0.047$ & $-0.62 /-0.31$ & $<0.0001 / 0.046$ \\
$\mathrm{TNF}-\alpha$ & $-0.30 /-0.25$ & $0.016 / 0.032$ & $-0.24 /-0.23$ & $0.047 / 0.048$ \\
IL-6 & $0.28 /-0.13$ & $0.131 / 0.323$ & $0.26 /-0.11$ & $0.157 / 0.420$ \\
Adiponectin & $0.33 / 0.23$ & $0.011 / 0.029$ & $0.36 / 0.25$ & $0.010 / 0.021$ \\
Visfatin & $-0.42 /-0.31$ & $0.012 / 0.018$ & $-0.30 /-0.29$ & $0.019 / 0.023$ \\
Resistin & $-0.15 /-0.37$ & $0.167 / 0.004$ & $-0.13 /-0.28$ & $0.276 / 0.032$ \\
\hline
\end{tabular}

$\mathrm{M}=$ male; $\mathrm{F}=$ female; $\mathrm{CRP}=\mathrm{C}$-reactive protein; IL-6 = interleukin $6 ; \mathrm{TNF}-\alpha=$ tumor necrosis factor alpha

Table 5. Results of multiple stepwise regression analysis with serum bilirubin (total) as a dependent variable in male and female subjects

\begin{tabular}{|l|l|l|l|l|}
\hline \multirow{2}{*}{$\begin{array}{l}\text { Independent } \\
\text { variable }\end{array}$} & \multicolumn{3}{|l|}{ Male } & \multicolumn{2}{l|}{ Female } \\
\cline { 2 - 5 } CRP & $\beta$ & $\mathrm{p}$ & $\beta$ & $\mathrm{p}$ \\
\hline TNF- $\alpha$ & -0.53 & 0.020 & -0.22 & $\mathrm{NS}$ \\
IL-6 & -0.15 & $\mathrm{~ns}$ & -0.14 & $\mathrm{NS}$ \\
Adiponectin & 0.13 & $\mathrm{~ns}$ & -0.08 & $\mathrm{NS}$ \\
Visfatin & 0.21 & $\mathrm{~ns}$ & 0.22 & $\mathrm{NS}$ \\
Resistin & -0.46 & 0.006 & -0.28 & 0.039 \\
\hline
\end{tabular}

$\mathrm{CRP}=\mathrm{C}$-reactive protein; IL-6 = interleukin 6 ; TNF- $\alpha=$ tumor necrosis factor alpha; $\mathrm{NS}=$ nonsignificant

Variables included in the model were CRP, TNF- $\alpha$, IL-6, adiponectin, resistin and visfatin. Only significant $\mathrm{p}$ values are shown in multivariate analysis $(\mathrm{p}<0.05)$.

We detected a significant negative association between total bilirubin and CRP, TNF- $\alpha$, visfatin and resistin values, and a significant positive association between total serum bilirubin and adiponectin values $(\mathrm{p}<0.05$ all) (Table 3), before stratifying subjects on the basis of BMI. Importantly, after BMI adjustment, we found a significant negative association between total serum bilirubin levels and both visfatin $(-0.29 ; \mathrm{p}=0.034)$ and CRP $(-0.33 ; p=0.001)$ serum levels. Due to the known relationship between BMI and bilirubin levels, both associations were less strong, but still statistically significant.

Moreover, Table 4 shows the results of linear regression analysis between the level of the dependent variable of serum bilirubin (total and direct) and CRP, TNF- $\alpha$, visfatin, resistin, adiponectin and IL-6. All as- sociations except for resistin were stronger and more significant in males than in females.

\section{Adipokines as predictors of serum bilirubin level}

Results of multiple stepwise regression analyses with serum bilirubin (total) as a dependent variable in male and female subjects are presented in Table 5. Visfatin was strong and gender nonspecific predictor of serum bilirubin. Furthermore, CRP was predictor of serum bilirubin in male individuals, and resistin in female subjects.

To further examine the effects of adipokines on serum bilirubin level, we also performed hierarchical multiple regression analysis, as shown in Table 6. The hierarchical multiple regression revealed that at stage one, general parameters, e.g., age and gender, contributed to the regression model and accounted for $13 \%$ of the variation in serum levels of bilirubin. Introducing obesity parameters in stage two of the regression model (e.g., waist to hip ratio and body fat mass) explained additional $4 \%$ of the variation in serum level of bilirubin. In addition, the results of the regression in step 3 indicated that four predictors (fasting glucose, insulin, triacylglycerols and total cholesterol) explained an additional $24 \%$ of the variation in serum level of bilirubin, and change in $R^{2}$ was significant $(\mathrm{p}<0.01)$. Step 4 was also significant with adipokines and CRP as important predictors of serum bilirubin level (visfatin and CRP significantly contributed to the explained variation of serum bilirubin level) and explained 11\% of the variation of serum bilirubin level. It was found that the level of serum bilirubin was significantly predicted by body fat mass $(\beta=-0.436, p<0.05)$, slightly more as did fasting insulin $(\beta=-0.415, p<0.01)$, visfatin 
Table 6. Results of hierarchical multiple regression analysis for variables predicting serum bilirubin levels

\begin{tabular}{|l|l|l|l|}
\hline & \multicolumn{3}{|l|}{$\begin{array}{l}\text { Dependent variable } \\
\text { - bilirubin }\end{array}$} \\
\hline Predictor & $\beta$ & $F$ & $\Delta R^{2}$ \\
\hline Step 1: & & 4.40 & $0.13^{*}$ \\
Age & -0.243 & & \\
Gender & -0.216 & & \\
\hline Step 2: & & 2.82 & $0.04^{*}$ \\
Waist to hip ratio & -0.203 & & \\
Body fat mass & $-0.436^{*}$ & & \\
\hline Step 3: & & 4.47 & $0.24^{* *}$ \\
Fasting glucose & -0.123 & & \\
Fasting insulin & $-0.415^{* *}$ & & \\
Triacylglycerols & $-0.301^{*}$ & & \\
Total cholesterol & -0.176 & & \\
\hline Step 4: & & 4.01 & $0.11^{* *}$ \\
CRP & $-0.284^{*}$ & & \\
Visfatin & $-0.321^{*}$ & & \\
Resistin & -0.145 & & \\
Adiponectin & 0.189 & & \\
IL-6 & 0.165 & & \\
TNF- $\alpha$ & -0.197 & & \\
\hline Total $R^{2}$ & & & $0.52^{* *}$ \\
\hline N & & & 96 \\
\hline
\end{tabular}

\#BMI = body mass index; $\mathrm{CRP}=\mathrm{C}$-reactive protein; IL-6 = interleukin 6; TNF- $\alpha=$ tumor necrosis factor alpha; * $\mathrm{p}<0.05$, and ** $\mathrm{p}<0.01$

$(\beta=-0.321, p<0.05)$, serum triacylglycerols $(\beta=-0.301$, $\mathrm{p}<0.05)$ and CRP $(\beta=-0.284, \mathrm{p}<0.05)$. Together, the adjusted $R^{2}$ value was 0.52 . This indicated that $52 \%$ of the variance in serum level of bilirubin was explained by the proposed model.

\section{Discussion}

In this study, we demonstrated for the first time that total serum bilirubin levels in overweight and normal weight middle-aged asymptomatic subjects were negatively associated with some proinflammatory adipokines, such as visfatin and resistin, and inflammatory cytokines such as TNF- $\alpha$, IL- 6 and CRP, whereas serum bilirubin was positively associated with anti-inflammatory adiponectin. Moreover, serum lev- els of CRP, visfatin, and resistin were strong predictors of serum bilirubin levels.

Bilirubin in normal concentration is a potent endogenous antioxidant and anti-inflammatory agent in serum, which can neutralize free radicals, prevent peroxidation of lipids, and decrease oxidative stress ${ }^{23}$. Indeed, in our study, we observed an inverse relationship between serum bilirubin levels and pro-inflammatory cytokines (TNF- $\alpha$, IL-6) and CRP, thereby confirming the anti-inflammatory activity of bilirubin, as previously described ${ }^{24}$. Our data are in agreement with other studies, describing that total bilirubin was inversely correlated with CRP in overweight subjects ${ }^{8,12,25}$. In addition, in our study, CRP level was a predictor of serum bilirubin in male individuals. On the other hand, weight loss is associated with a rapid increase in total bilirubin levels and antioxidant capacity ${ }^{12,25}$.

We showed that adiponectin, which is an anti-inflammatory adipokine, was positively correlated with serum bilirubin levels in asymptomatic middle-aged individuals. Previously, positive correlation of adiponectin with serum bilirubin was described in non-diabetic men; however, in comparison to our study, those subjects were older, some were symptomatic (hypertension, microalbuminuria), and/or smokers, which all can affect serum bilirubin levels ${ }^{21}$. Many other studies described this correlation in patients with liver cell injury, e.g., cirrhosis and cholestasis ${ }^{26}$. It is important to notice that both serum bilirubin ${ }^{6}$ and serum adiponec$\operatorname{tin}^{5,27}$ have beneficial effects in a variety of CVD. Moreover, both show negative correlation with obesity and $\mathrm{BMI}^{5,9}$.

The physiology of bilirubin and adiponectin also combines in the heme oxygenase-adiponectin axis response. Heme oxygenase- 1 system is involved in enhancing adiponectin synthesis and release ${ }^{28}$. Pathologic conditions such as oxidative stress and inflammation up-regulate the level of inducible heme oxygenase (HO-1), thereby increasing total bilirubin levels ${ }^{29}$. Overexpression of $\mathrm{HO}-1$ resulted in a marked increase in adiponectin with a corresponding decrease in the levels of inflammatory cytokines TNF- $\alpha, \mathrm{IL}-1 \beta$ and IL-6 in animal models of obesity ${ }^{20,30}$. Indeed, we observed a correlation between TNF- $\alpha$ and serum bilirubin, but there was no correlation with IL-6. Moreover, $\mathrm{HO}-1$ induction alters the physical appearance of adipocytes, i.e. from few large to many smaller adipo- 
cytes $^{31}$. These modified adipocytes led to increases in anti-inflammatory AMPK, PPAR $\gamma$, and adiponectin, whereas on the other hand, they decreased the production of inflammatory cytokines such as TNF- $\alpha$ and IL- $6{ }^{31}$. Furthermore, HO-1 induction was found to be beneficial in obesity by inhibiting adipogenesis, i.e. preventing the formation of adipose tissue from mesenchymal stem cells ${ }^{32}$. Indeed, diabetic patients have reduced HO-1 responses to chronic inflammation and oxidative stress, and thus consequently lower serum bilirubin and adiponectin levels ${ }^{33}$.

Herewith we report for the first time a strong negative association between serum visfatin and bilirubin levels. In addition, we found higher serum visfatin levels in overweight subjects in comparison to the normal weight ones, which is in agreement with previous studies $^{22,34}$. Increased serum visfatin levels are associated with the obesity-related morbidities ${ }^{35}$, higher presence of coronary artery disease ${ }^{36}$, and higher risk of acute myocardial infarction ${ }^{37}$. Visfatin was positively associated with insulin resistance, and thus suggested as a biomarker for predicting obesity, diabetes status, insulin resistance, metabolic syndrome and $\mathrm{CVDs}^{34}$. In previous studies, increased visfatin levels and increased bilirubin levels have been reported in patients with liver diseases, e.g., chronic viral hepatitis ${ }^{38}$. Indeed, obese individuals with healthy liver function can have increased visfatin levels similar to the patients with non-alcoholic fatty liver disease ${ }^{39}$. Thus, negative correlation between serum bilirubin and visfatin applies only to the individuals with no liver disease.

A major limitation of our cross-sectional study was a small number of subjects enrolled. Thus, a prospective study involving a larger number of subjects is necessary to confirm the correlation between serum bilirubin and studied adipokines, and to further investigate low serum bilirubin levels as a cardiovascular risk factor in overweight subjects. Secondly, our study assumed that total bilirubin levels correlated with free bilirubin, which is the unconjugated and unbound bilirubin $^{40}$. It is the bioactive form, but it is not routinely measured in clinical settings; however, in healthy adults, its concentration is around $10 \mathrm{nM}^{41}$. To better elucidate the bilirubin mechanisms of actions on adipocytes, free bilirubin values should be employed in future studies.

There is only scarce evidence for bilirubin effects on adipocytes. However, bilirubin can act as: (i) direct radical scavenger of reactive oxygen species (ROS) and nitrogen species since reduced oxidative stress in adipocytes decreases the activation of the intracellular ASK1-MEK4-JNK signaling pathway that is crucial in insulin resistance ${ }^{42}$; (ii) inhibitor of NAPDH oxidase, which is the most important source of intracellular adipocyte ROS production ${ }^{42}$; and (iii) activator of peroxisome-proliferator-activated receptor $\alpha$ $(\mathrm{PPARa})^{43}$. Another possible explanation could be the anti-inflammatory effects of bilirubin on activated macrophages in hypertrophic visceral adipose tissue, which also express high levels of NADPH oxidase ${ }^{44}$.

Overall, serum bilirubin has been previously shown to be decreased in asymptomatic individuals before the onset of metabolic syndrome, on the basis of correlation with body weight, fat level, insulin resistance, LDL, HDL, triacylglycerols, CRP and physical activity. Here we further support this view by presenting that altered adipokine levels decrease in anti-inflammatory adiponectin and increase in pro-inflammatory visfatin are also correlated with lower serum bilirubin levels. Importantly, this study was conducted in asymptomatic, nonsmoking, middle-aged individuals with stable body weight, who are the key population for CVD prevention. This study opens the perspective of measuring adipose tissue dysfunction by serum biomarkers such as adipokines and bilirubin, and studying their role in the early pathogenesis of metabolic syndrome.

\section{Acknowledgments}

The authors gratefully acknowledge voluntary participation of all study subjects. This work was financially supported by the University of Primorska, Faculty of Health Sciences for the project entitled A Multidisciplinary Approach in the Treatment of Obesity; by the Slovenian Research Agency for research programs P1-0386 and P3-0067, and project J3-8209 (Bilirubin as a Protective Factor Against the Development of Chronic Degenerative Diseases: Serum Biomarker and Potential for Pharmacological Modulation); and the European Regional Development Fund, Cross-Border Cooperation Italy-Slovenia Program 2007-2013 (EU strategic project TRANS2CARE).

\section{References}

1. Stępień M, Wlazeł RN, Paradowski M, Banach M, Rysz M, Misztal M, Rysz J. Serum concentrations of adiponectin, leptin, 
resistin, ghrelin and insulin and their association with obesity indices in obese normo- and hypertensive patients - pilot study. Arch Med Sci. 2012;8:431-6. doi: 10.5114/aoms.2012.29397.

2. Klisić A, Kavarić N, Bjelaković B, Soldatović I, Martinović M, Kotur-Stevuljević J. The association between retinol-binding protein 4 and cardiovascular risk score is mediated by waist circumference in overweight/obese adolescent girls. Acta Clin Croat. 2017;56:92-8. doi: 10.20471/acc.2017.56.01.14.

3. Salha T, Andrijević D, Vrselja Z, Šerić V, Radić R, Curic G. Chemerin blood levels are associated with MRI measured volumes of abdominal adipose tissue compartments and lifestyle choices. Acta Clin Croat. 2017;56:663-72. doi: 10.20471/ acc.2017.56.04.13.

4. Coelho M, Oliveira T, Fernandes R. Biochemistry of adipose tissue: an endocrine organ. Arch Med Sci. 2013;9:191-200. doi: 10.5114/aoms.2013.33181.

5. Fantuzzi G. Adipose tissue, adipokines, and inflammation. J Allergy Clin Immunol. 2005;115:911-9. doi: 10.1016/j.jaci. 2005.02.023

6. Vitek L. The role of bilirubin in diabetes, metabolic syndrome, and cardiovascular diseases. Front Pharmacol. 2012;3:55. doi: 10.3389/fphar.2012.00055. doi: 10.3389/fphar.2012.00055

7. Vitek L, Bellarosa C, Tiribelli C. Induction of mild hyperbilirubinemia: hype or real therapeutic opportunity? Clin Pharmacol Ther. 2019;106(3):568-75. doi: 10.1002/cpt.1341.

8. Yoshino S, Hamasaki S, Ishida S, Kataoka T, Yoshikawa A, Oketani N, Saihara K, Okui H, Shinsato T, Ichiki H, Kubozono T, Kuwahata S, Fujita S, Kanda D, Nakazaki M, Miyata $\mathrm{M}$, Tei C. Relationship between bilirubin concentration, coronary endothelial function, and inflammatory stress in overweight patients. J Atheroscler Thromb. 2011;18:403-12. doi: 10.5551/jat.6346

9. Choi SH, Yun KE, Choi HJ. Relationships between serum total bilirubin levels and metabolic syndrome in Korean adults. Nutr Metab Cardiovasc Dis. 2013;23:31-7. doi: 10.1016/j.numecd.2011.03.001.

10. Lin L-Y, Kuo H-K, Hwang J-J, Lai LP, Chiang FT, Tseng CD, Lin JL. Serum bilirubin is inversely associated with insulin resistance and metabolic syndrome among children and adolescents. Atherosclerosis. 2009;203:563-8. doi: 10.1016/j.atherosclerosis.2008.07.021.

11. Seyed Khoei N, Grindel A, Wallner M, Mölzer C, Doberer D, Marculescu R, Bulmer A, Wagner KH. Mild hyperbilirubinaemia as an endogenous mitigator of overweight and obesity: implications for improved metabolic health. Atherosclerosis. 2017; pii: S0021-9150(17)31440-5. doi: 10.1016/j.atherosclerosis.2017.12.021.

12. Andersson C, Weeke P, Fosbøl EL, Brendorp B, Køber L, Coutinho W, Sharma AM, Van Gaal L, Finer N, James WP, Caterson ID, Rode RA, Torp-Pedersen C; SCOUT Executive Steering Committee; SCOUT investigators. Acute effect of weight loss on levels of total bilirubin in obese, cardiovascular high-risk patients: an analysis from the lead-in period of the
Sibutramine Cardiovascular Outcome trial. Metabolism. 2009; 58:1109-15. doi: 10.1016/j.metabol.2009.04.003.

13. Jenko-Pražnikar Z, Petelin A, Jurdana M, Žiberna L. Serum bilirubin levels are lower in overweight asymptomatic middleaged adults: an early indicator of metabolic syndrome? Metabolism. 2013;62:976-85. doi: 10.1016/j.metabol.2013.01.011.

14. Guzik TJ, Mangalat D, Korbut R. Adipocytokines - novel link between inflammation and vascular function? J Physiol Pharmacol. 2006;57:505-28.

15. Steppan CM, Bailey ST, Bhat S, Brown EJ, Banerjee RR, Wright CM, Patel HR, Ahima RS, Lazar MA. The hormone resistin links obesity to diabetes. Nature. 2001;409:307-12. doi: 10.1038/35053000.

16. Yamauchi T, Kadowaki T. Adiponectin receptor as a key player in healthy longevity and obesity-related diseases. Cell Metab. 2013;17:185-96. doi: 10.1016/j.cmet.2013.01.001.

17. Prakash J, Mittal B, Awasthi S, Agarwal CG, Srivastava N. Hypoadiponectinemia in obesity: association with insulin resistance. Indian J Clin Biochem. 2013;28:158-63. doi: 10.1007/ s12291-012-0246-3.

18. Blüher M. Adipokines - removing road blocks to obesity and diabetes therapy. Mol Metab. 2014;3:230-40. doi: 10.1016/j. molmet.2014.01.005.

19. Di Chiara T, Argano C, Corrao S, Scaglione R, Licata G. Hypoadiponectinemia: a link between visceral obesity and metabolic syndrome. J Nutr Metab. 2012;2012:175245. doi: 10.1155 /2012/175245..

20. Kim DH, Burgess AP, Li M, Tsenovoy PL, Addabbo F, McClung JA, Puri N, Abraham NG. Heme oxygenase-mediated increases in adiponectin decrease fat content and inflammatory cytokines, tumor necrosis factor-alpha and interleukin-6 in Zucker rats and reduce adipogenesis in human mesenchymal stem cells. J Pharmacol Exp Ther. 2008;325:833-40. doi: 10.1124/jpet.107.135285.

21. Dullaart RP, Boersema J, Lefrandt JD, Wolffenbuttel BH, Bakker SJ. The inverse association of incident cardiovascular disease with plasma bilirubin is unaffected by adiponectin. Atherosclerosis. 2014;235:380-3. doi: 10.1016/j.atherosclerosis. 2014.05.938.

22. Jurdana M, Petelin A, Černelič Bizjak M, Bizjak M, Biolo G, Jenko-Pražnikar Z. Increased serum visfatin levels in obesity and its association with anthropometric/biochemical parameters, physical inactivity and nutrition. e-SPEN Journal. 2013; 8:e59-e67.23.

23. Belanger S, Lavoie JC, Chessex P. Influence of bilirubin on the antioxidant capacity of plasma in newborn infants. Biol Neonate. 1997;71:233-8. doi: 10.1159/000244422

24. Vogel ME, Zucker SD. Bilirubin acts as an endogenous regulator of inflammation by disrupting adhesion molecule-mediated leukocyte migration. Inflamm Cell Signal. 2016;3(1). pii: e1178. doi: 10.14800/ics.1178.

25. Melissas J,Malliaraki N, Papadakis JA, Taflampas P, Kampa M, Castanas E. Plasma antioxidant capacity in morbidly obese pa- 
tients before and after weight loss. Obes Surg. 2006;16:314-20. doi: 10.1381/096089206776116444.

26. Salman TA, Allam N, Azab GI, Shaarawy AA, Hassouna MM, El-Haddad OM. Study of adiponectin in chronic liver disease and cholestasis. Hepatol Int. 2010;4:767-74. doi: 10.1007/ s12072-010-9216-0

27. Kawagoe J, Ishikawa T, Iwakiri H, Date H, Imamura T, Kitamura K. Association between adiponectin production in coronary circulation and future cardiovascular events in patients with coronary artery disease. Int Heart J. 2014;55:239-43. doi: 10.1536/ihj.13-287.

28. Nicolai A, Li M, Kim DH, Peterson SJ, Vanella L, Positano V, Gastaldelli A, Rezzani R, Rodella LF, Drummond G, Kusmic C, L'Abbate A, Kappas A, Abraham NG. Heme oxygenase-1 induction remodels adipose tissue and improves insulin sensitivity in obesity-induced diabetic rats. Hypertension. 2009;53: 508-15. doi: 10.1161/HYPERTENSIONAHA.108.124701.

29. Hosick PA, Stec DE. Heme oxygenase, a novel target for the treatment of hypertension and obesity? Am J Physiol Regul Integr Comp Physiol. 2012;302:R207-14. doi: 10.1152/ajpregu.00517.2011.

30. Li M, Kim DH, Tsenovoy PL, Peterson SJ, Rezzani R, Rodella LF, Aronow WS, Ikehara S, Abraham NG. Treatment of obese diabetic mice with a heme oxygenase inducer reduces visceral and subcutaneous adiposity, increases adiponectin levels, and improves insulin sensitivity and glucose tolerance. Diabetes. 2008;57:1526-35. doi: 10.2337/db07-1764.

31. Burgess A, Li M, Vanella L, Kim DH, Rezzani R, Rodella L, Sodhi K, Canestraro M, Martasek P, Peterson SJ, Kappas A, Abraham NG. Adipocyte heme oxygenase- 1 induction attenuates metabolic syndrome in both male and female obese mice. Hypertension. 2010;56:1124-30. doi: 10.1161/HYPERTENSIONAHA.110.151423.

32. Kim DH, Vanella L, Inoue K, Burgess A, Gotlinger K, Manthati VL, Koduru SR, Zeldin DC, Falck JR, Schwartzman ML, Abraham NG. Epoxyeicosatrienoic acid agonist regulates human mesenchymal stem cell-derived adipocytes through activation of HO-1-pAKT signaling and a decrease in PPAR . Stem Cells Dev. 2010;19:1863-73. doi: 10.1089/scd.2010.0098.

33. Issan Y, Hochhauser E, Kornowski R, Leshem-Lev D, Lev E, Sharoni R, Vanella L, Puri N, Laniado-Schwartzman M, Abraham NG, Porat E. Endothelial progenitor cell function inversely correlates with long-term glucose control in diabetic patients: association with the attenuation of the heme oxygenase-adiponectin axis. Can J Cardiol. 2012;28:728-36. doi: 10.1016/j.cjca.2012.01.013.
34. Chang YH, Chang DM, Lin KC, Shin SJ, Lee YJ. Visfatin in overweight/obesity, type 2 diabetes mellitus, insulin resistance, metabolic syndrome and cardiovascular diseases: a meta-analysis and systematic review. Diabetes Metab Res Rev. 2011; 27:515-27. doi: 10.1002/dmrr.1201.

35. Ooi SQ, Chan RM, Poh LK, Loke KY, Heng CK, Chan YH, Gan SU, Lee KO, Lee YS. Visfatin and its genetic variants are associated with obesity-related morbidities and cardiometabolic risk in severely obese children. Pediatr Obes. 2014;9: 81-91. doi: 10.1111/j.2047-6310.2013.00149.x.

36. Lu YC, Hsu CC, Yu TH, Wang CP, Lu LF, Hung WC, Chiu CA, Chung FM, Lee YJ, Tsai IT. Association between visfatin levels and coronary artery disease in patients with chronic kidney disease. Iran J Kidney Dis. 2013;7:446-52.

37. Yang Y, Li Z, Tao HF, Qi XY, Wang WL, Yang L, Wang H, Xu P. An elevated plasma level of visfatin increases the risk of myocardial infarction. Genet Mol Res. 2014 24;13:8586-95. doi: 10.4238/2014.January.24.18.

38. Kukla M, Zwirska-Korczala K, Gabriel A, Waluga M, Warakomska I, Berdowska A, Rybus-Kalinowska B, Kalinowski M, Janczewska-Kazek E, Woźniak-Grygiel E, Kryczka W. Visfatin serum levels in chronic hepatitis C patients. J Viral Hepat. 2010;17:254-60. doi: 10.1111/j.1365-2893.2009.01174.x.

39. Jarrar MH, Baranova A, Collantes R, Ranard B, Stepanova M, Bennett C, Fang Y, Elariny H, Goodman Z, Chandhoke V, Younossi $\mathrm{ZM}$. Adipokines and cytokines in non-alcoholic fatty liver disease. Aliment Pharmacol Ther. 2008;27:412-21.

40. Wennberg RP. Measuring free bilirubin: the clinical perspective. Clin Chem. 2012;58:811-3. doi: doi: 10.1373/clinchem.2012.183962.

41. Martelanc M, Žiberna L, Passamonti S, Franko M. Direct determination of free bilirubin in serum at sub-nanomolar levels. Anal Chim Acta. 2014;809:174-82. doi: 10.1016/j.aca.2013. 11.041.

42. DiNicolantonio JJ, McCarty MF, O'Keefe JH. Antioxidant bilirubin works in multiple ways to reduce risk for obesity and its health complications. Open Heart. 2018;5:e000914. doi: 10.1136/openhrt-2018-000914.

43. Hinds TD Jr, Adeosun SO, Alamodi AA, Stec DE. Does bilirubin prevent hepatic steatosis through activation of the PPAR $\alpha$ nuclear receptor? Med Hypotheses. 2016;95:54-57. doi: 10.1016/j.mehy.2016.08.013.

44. Hinds TD Jr, Stec DE. Bilirubin, a cardiometabolic signaling molecule. Hypertension. 2018;72:788-95. doi: 10.1161/HYPERTENSIONAHA.118.11130. 
Sažetak

\section{SERUMSKI BILIRUBIN KORELIRA S ADIPOKINIMA U SERUMU KOD ASIMPTOMATSKIH ODRASLIH OSOBA S NORMALNOM I PREKOMJERNOM TJELESNOM TEŽINOM}

\section{A. Petelin, M. Jurdana, Z. Jenko Pražnikar i L. Žiberna}

Prekomjerna tjelesna težina i pretilost smatraju se kroničnom upalom niskog stupnja praćenom neuravnoteženom proizvodnjom adipokina. Cilj istraživačkog rada bio je razjasniti odnos između serumskog bilirubina, koji je endogeni antioksidans s protuupalnom aktivnošću, i pro- i protuupalnih serumskih adipokina kod asimptomatskih pojedinaca s normalnom i pojedinaca s prekomjernom tjelesnom težinom. U ovoj presječnoj studiji sudjelovali su zdravi muškarci i žene u dobi od 25 do 49 godina. Mjereni su biokemijski parametri, adipokini, interleukin-6 (IL-6), faktor tumorske nekroze (TNF- $\alpha$ ), C-reaktivni protein (CRP), ukupni i direktni serumski bilirubin. Sudionici su bili podijeljeni u dvije skupine: osobe s normalnom i osobe s prekomjernom tjelesnom težinom. Pronašli smo statistički značajnu negativnu povezanost između ukupnog bilirubina i vrijednosti CRP, TNF- $\alpha$, visfatina i rezistina te statistički značajnu pozitivnu povezanost između ukupnog bilirubina i adiponektina u objema skupinama. Dodatno, nakon prilagodbe indeksa tjelesne mase našli smo značajnu negativnu povezanost između ukupnog bilirubina te visfatina i CRP. Multivarijatna logistička regresijska analiza je pokazala da su visfatin, rezistin i CRP prediktori ukupnog bilirubina.

Ključne riječi: Adipokini; Bilirubin; C-reaktivni protein; Prekomjerna težina; Pretilost; Presječno istraživanje 